Scientific Review - Engineering and Environmental Sciences (2018), 27 (4), 410-424

Sci. Rev. Eng. Env. Sci. (2018), 27 (4)

Przegląd Naukowy - Inżynieria i Kształtowanie Środowiska (2018), 27 (4), 410-424

Prz. Nauk. Inż. Kszt. Środ. (2018), 27 (4)

http://iks.pn.sggw.pl

DOI 10.22630/PNIKS.2018.27.4.40

\author{
Moses E. EMETERE ${ }^{1,2}$, Samuel E. SANNI ${ }^{3}$, Emmanuel E. OKORO ${ }^{3}$, \\ Gideon A. ADEYEMI ${ }^{1}$ \\ ${ }^{1,2}$ College of Science and Technology, Covenant University Canaan land \\ ${ }^{2}$ School of Mechanical Engineering and Science, University of Johannesburg \\ ${ }^{3}$ College of Engineering, Covenant University
}

\title{
Aerosol loading and its effect on respiratory dysfunction disorder over Dapaong-Togo
}

Key words: air pollution, aerosol, Dapaong, respiratory, model

\section{Introduction}

Atmospheric aerosols (AA) is dangerous to human health when the emission rate is presumably high. The water-soluble part of atmospheric aerosol particle originates from gas to particle conversion and consists of various kinds of sulphates, nitrates, organic and water-soluble substances. The soot is made-up of incombustible black carbon. Mineral aerosol or desert dust consists of a mixture of quartz and clay minerals. Antarctic aerosol or sulphate aerosol consists of a large amount of sulphate, that is, $75 \% \mathrm{H}_{2} \mathrm{SO}_{4}$. When AA is inhaled in large volume/quantity, it deposits in the lungs and undergoes chemical changes, particularly when passing through the lungs to other sensitive organs of the body. Hence, aside respiratory dysfunction, inhalation of atmospheric aerosols may lead to cancer, arrhythmias, atrial fibrillation, acute coronary syndromes, cardiovasculer malfunction etc.

The science of the aerosol transport through the lungs is known (Newman, Clark, Talaee \& Clarke,1989; Hofmann \& Koblinger, 1992; Edwards, 1995; Goikoetxea et al., 2014) as well as the perculiarity of aerosol loading over West Africa (Emetere, Akinyemi \& Akinojo, 2015; Emetere 2016a, b, c) where the research site is located. In this study, we are interested in documenting numerical values of the current state of aerosol loading into the atmosphere, its sizes and the deposition efficiency of the atmospheric aerosols into human lungs. This information is very vital for furture work over Dapaong-Togo. 


\section{Experimental design, materials and methods}

Dapaong is located on latitude $10.8733^{\circ} \mathrm{N}$ and longitude $0.2010^{\circ} \mathrm{E}$ as shown on the Google map (Fig. 1). The primary data was obtained from Multi-angle Imaging Spectro-Radiometer (MISR). The aerosol retention and loading were obtained using the West African regional scale dispersion model (WASDM). This model has been proven to be reliable for calculating aerosol loading over the West African region. It is mathematically given as (Emetere, 2016b):

$$
\begin{aligned}
& \psi(\lambda)=a_{1}^{2} \cos \left(\frac{n_{1} \pi \tau(\lambda)}{2} x\right) \cos \left(\frac{n_{1} \pi \tau(\lambda)}{2} y\right)+\cdots \\
& \ldots+a_{n}^{2} \cos \left(\frac{n_{n} \pi \tau(\lambda)}{2} x\right) \cos \left(\frac{n_{n} \pi \tau(\lambda)}{2} y\right)
\end{aligned}
$$

a is atmospheric constant gotten from the fifteen years aerosol optical depth (AOD) dataset from MISR, $\mathrm{n}$ is the tuning constant, $\tau^{(\lambda)}$ is the AOD of the area and $\psi^{(\lambda)}$ is the aerosol loading.

The digital voltage and Angstrom parameters of the study area can be obtained from Equations (2) and (3) respectively.

$$
I(555)=\frac{I_{o}(555)}{R^{2}} \exp [m \cdot \tau(555)]
$$

where $I$ is the solar radiance over the SPM detector at wavelength $\lambda=555 \mathrm{~nm}$, $I_{o}$ is the is a measure of solar radiation behind the atmosphere, $R$ is the mean Earth-Sun distance in astronomical units, $\tau$ is the total optical depth (in this case, the average of the each month is referred to as the total AOD, and $\mathrm{m}$ is the optical air mass.

$$
\alpha=-\frac{\mathrm{d} \operatorname{In}(\tau)}{\mathrm{d} \operatorname{In}(\lambda)}
$$

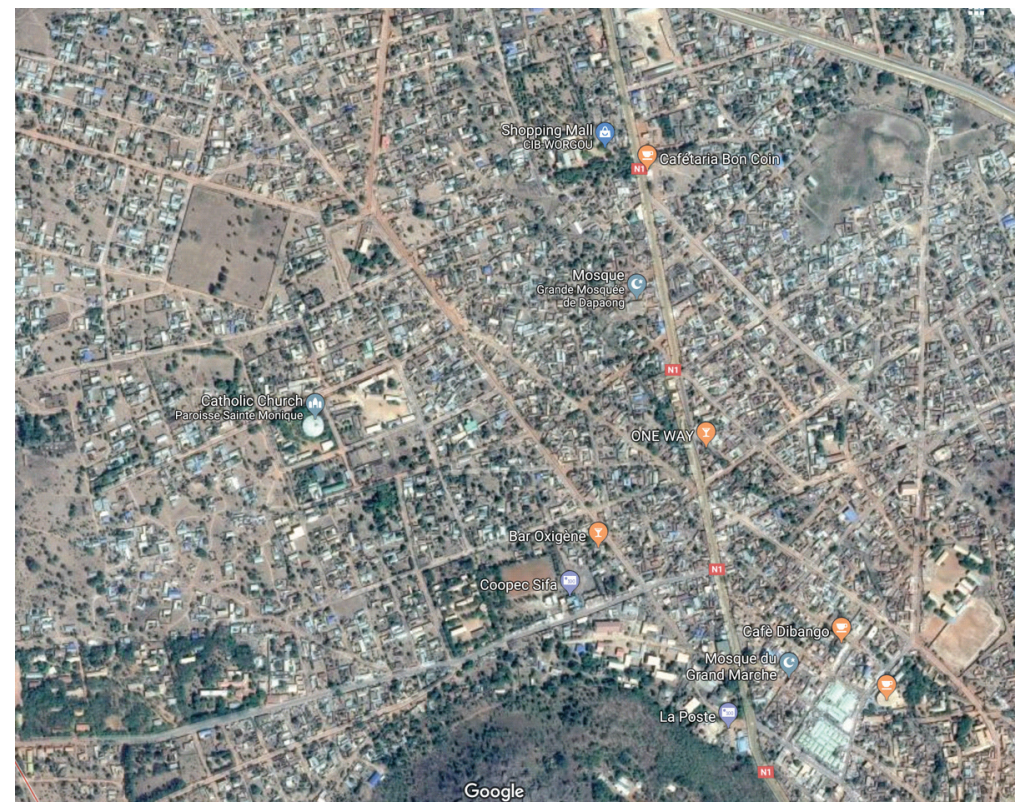

FIGURE 1. Google map over Dapaong 
where $\alpha$ is the Angstrom parameter, $\tau$ is the aerosol optical depth, and $\lambda$ is the wavelength. The radius of the particles for atmospheric aerosol was calculated using proposals by Kokhanovsky et al. (2006). The analysis of Equations (1-3) was done using the $\mathrm{C}++$ codes, Surfer software and Excel.

The aerosols deposition into the human lungs (Fig. 2) has been modelled as documented in Martonen and Zhang (1992), Darquenne and Kin (2004), Varghese and Gangamma (2006), Goikoetxea et al. (2014) and Ching and Kajino (2018).

$\eta=\left[1-\exp \left(-39.9 Q^{0.14} D^{0.599}\right)\right]+$ $+\left\{1+\exp \left[12.39-2.92 \log \left(\rho D_{p}^{2} Q\right)\right]^{-1}\right\}$

where $\eta$ is the deposition efficiency, $Q$ volumetric flow rate, $D$ is the diffusion coefficient of the particle, $D_{p}$ is the particle density and is the particle diameter.

The flowchart that summarized the methodology adopted to execute this research work is highlighted in Figure 3.

\section{Results and discussion}

Aerosol loading parameters are shown in Figures 4 and 5. The aerosol loading is high and almost constant at about 0.96 throughout fourteen years. This is an evidence that the source of the aerosol loading is sustainably influencing the risk of human to respiratory dysfunction. From literature, the sources of pollution is Sahara dust and anthropogenic pollution. The anthropogenic pollution may be inferred from the Google map presented in Figure 1. The anthropogenic sources include bush burning, automobile gas emission, domestic fuel burning

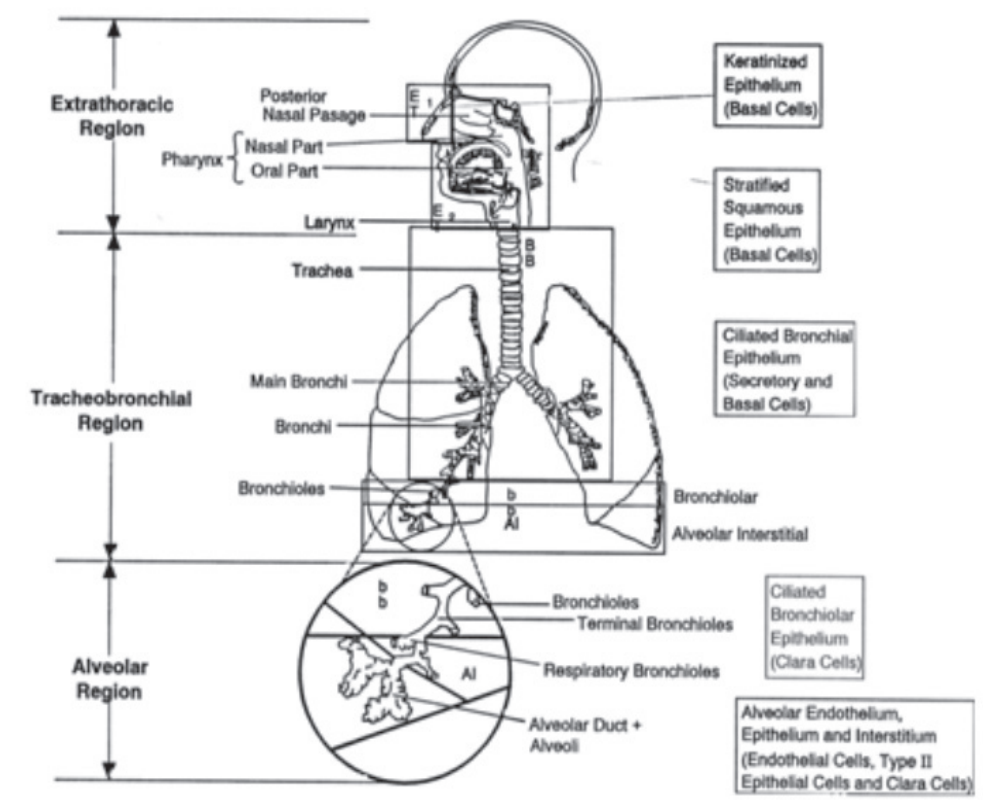

FIGURE 2. The respiratory component of the human being (Hofmann and Koblinger, 1992) 


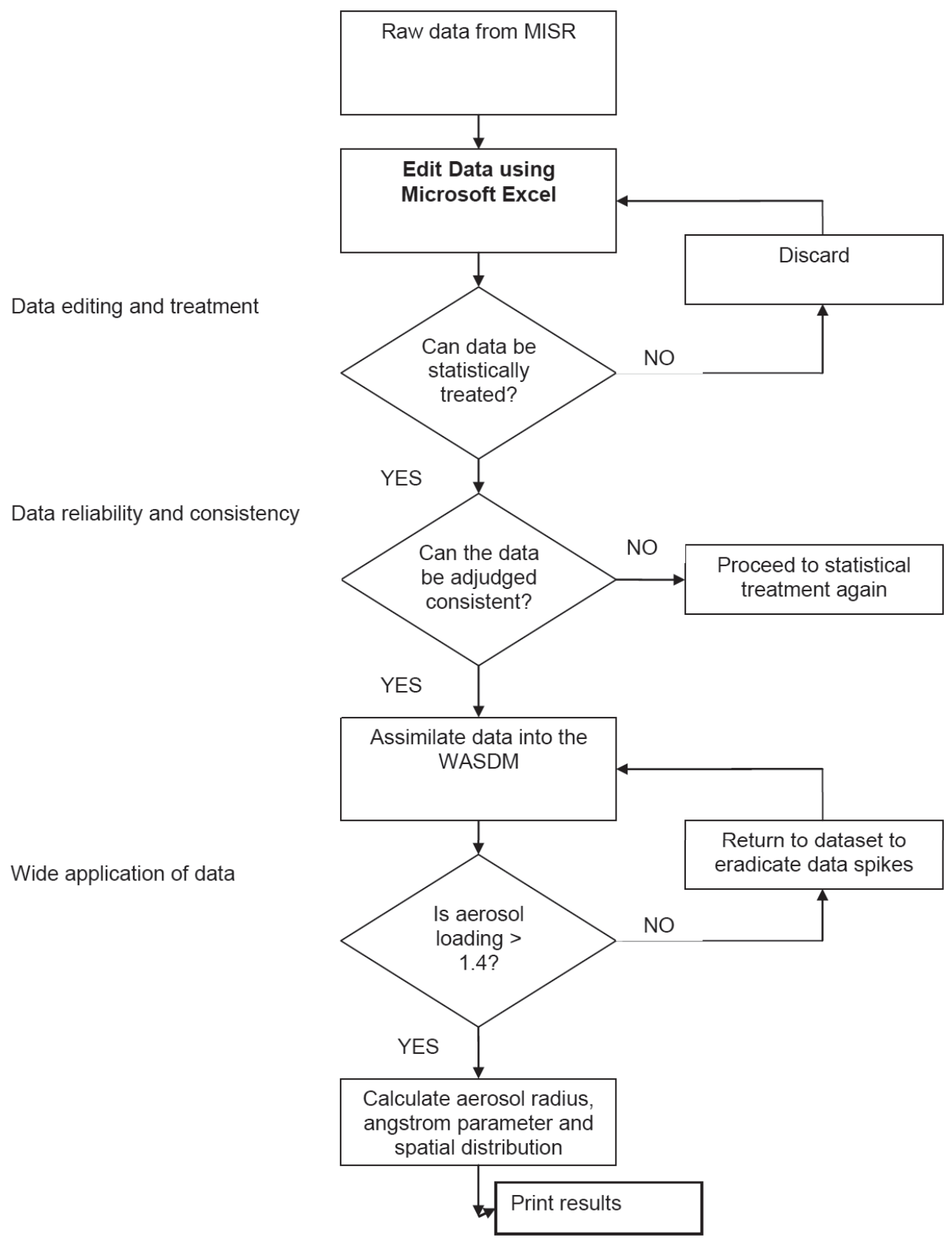

FIGURE 3. Flowchart of the research methodology 


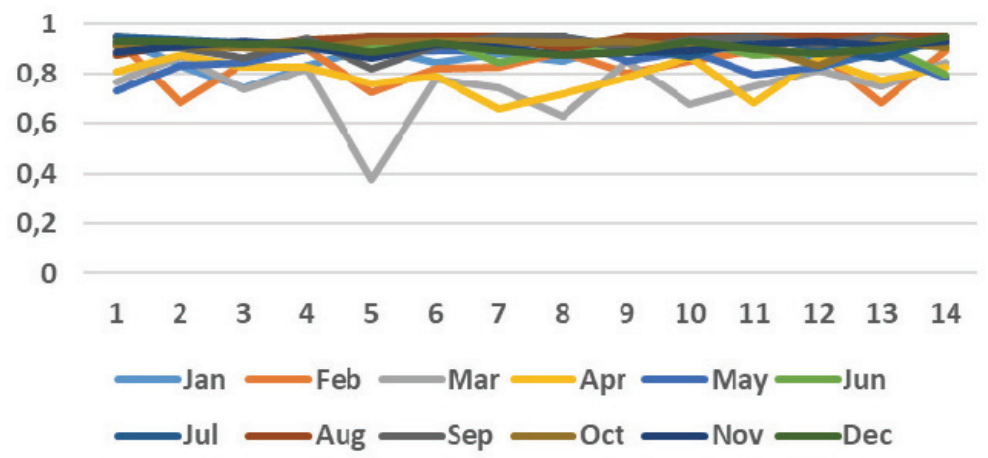

FIGURE 4. Aerosol loading versus years (2000-2013)

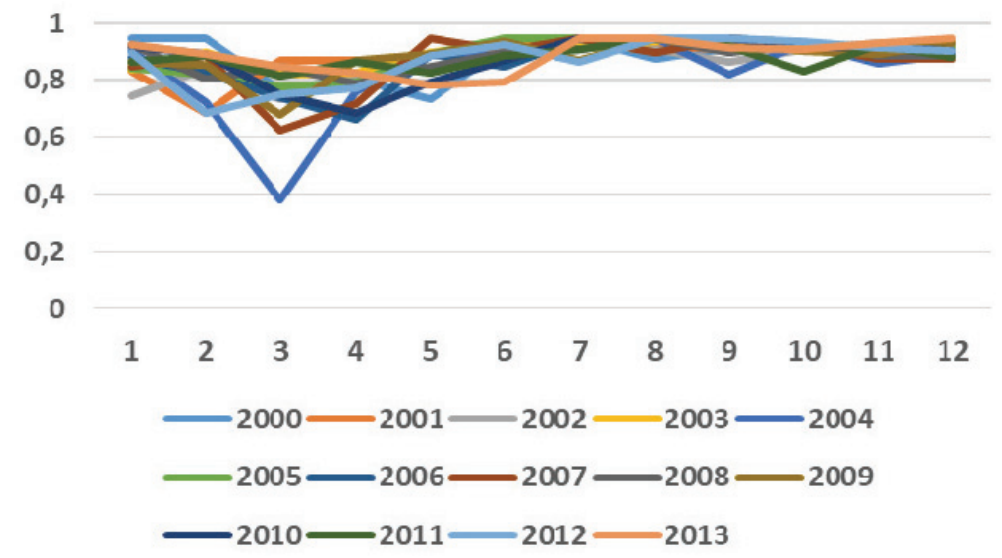

FIGURE 5. Aerosol loading versus month of year (2000-2013)

(e.g. fire wood, charcoal, kerosene etc.) the dependency of the aerosol optical and industrial emission. In Figure 4, thickness or aerosol extinction coeffithe highest aerosol loading for fourteen cient on wavelength. So when the Angyears was found to occur in March 2004. strom exponent is $<0.1$, the aerosols is However, in 2013, the highest aerosol likely black carbon, when the Angstrom loading was found to be in the month of exponent is $>0.1$, the aerosols is a mixMay. This may be due to climate change and it is an evidence of a dismal rainfall pattern over the area. In Figure 5, it was observed that the transient nature of the aerosol loading over the research area was between January and May. This result partly shows the period where Sahara dust flow is highest. The dominant pollutant can be traced from the Angstrom exponent, which describes ture of black carbon, dust and unknown pollutants. The lowest aerosol loading ever recorded was in March 2005 (Figs. 6 and 7). Over two decades, the aerosol loading is lowest between February and May while the highest aerosol loading is between June and January. It has been proven that precipitation rate lowers the aerosol loading in the atmosphere (Emetere, 2016a). The ANOVA of the aerosol 
loading is presented in Table 1. The coefficient of multiple determination is given as 0.35988 . The result in Table 1 further show that the source of the pollution is sustainable over fifteen years.

Some scientists have shown that the sizes of pollutants determine the danger that maybe encountered during inhalation of atmospheric aerosols. For example, $\mathrm{Yu}$ and $\mathrm{Xu}$ (1987) and Ching and Kajino (2018) worked on the regional and total deposition of $200 \mathrm{~nm}$ particles in the lungs of children and adult. It was observed that the total deposition in the tracheo-bronchial has risen by a factor of $20 \%$ in children relative to adults. This ascertion was experimentally validated by Bequemin, Yu, Roy and Bouchikhi (1990) and Schiller-Scotland, Hlawa, Gebhardt, Wönne and Heyder (1992). This was the motivation for the estima- tion of the aerosol/particulate radius over Dapaong. The aerosol radius fluctuated all through fifteen years (Fig. 6). The largest aerosol radius was found in March 2005 when the aerosol loading is presumably low. It leads to the first hypothesis that low aerosol loading indicates that the sizes of the aerosols is large. Hence at high aerosol loading, the aerosol radius is very small to penetrate the nostrils into the lungs. In the research area, soot from anthropogenic sources is more and visible via its deposition on surfaces of leaves and roofs. The coefficient of multiple determination is given as 0.445 . The ANOVA shown in Table 2 depicts that the aerosol radius is presumably low to affect respiratory process in human.

In Figures 8-10, we show the spatial distribution of aerosol optical depth, aer-

TABLE 1. ANOVA for aerosol loading at coefficient of multiple determination, $R^{2}=0.35987994954612$

\begin{tabular}{|l|c|c|c|c|}
\hline Source & $d f$ & $S S$ & $M S$ & $F$ \\
\hline Regression & 2 & 0.0176 & 0.0088 & 2.5299 \\
\hline Residual & 9 & 0.0313 & 0.0034 & $\times$ \\
\hline Total & 11 & 0.0489 & $\times$ & $\times$ \\
\hline
\end{tabular}

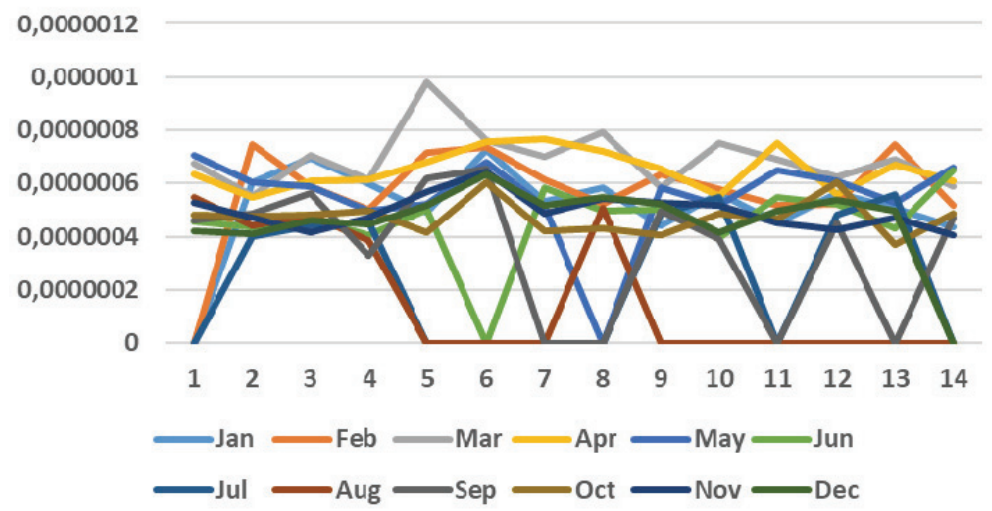

FIGURE 6. Atmospheric aerosol radius versus month of year (2000-2013) 


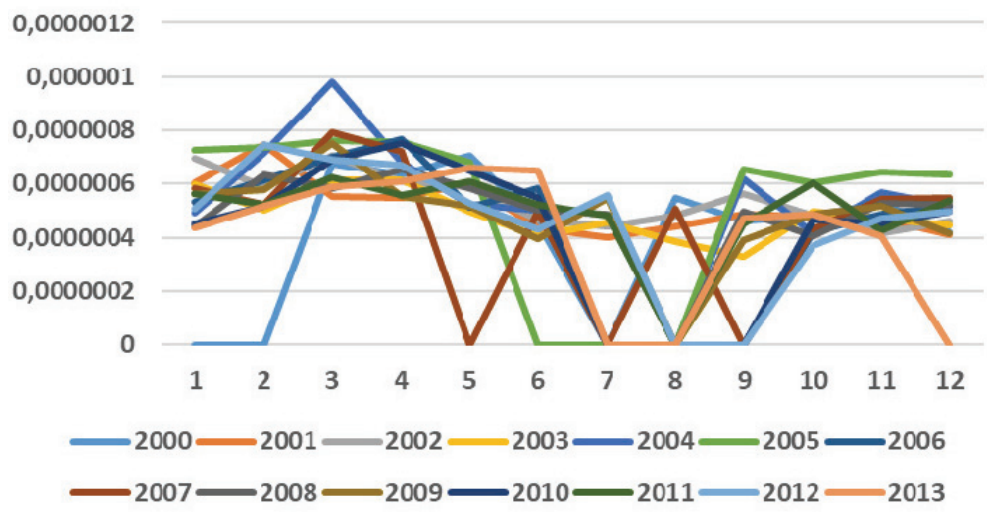

FIGURE 7. Atmospheric aerosol radius versus month of year (2000-2013)

TABLE 2. ANOVA for aerosol radius at coefficient of multiple determination $R^{2}=0.44999742735105$

\begin{tabular}{|l|c|c|c|c|}
\hline Source & $d f$ & $S S$ & $M S$ & $F$ \\
\hline Regression & 2 & $3.5373 \mathrm{E}-014$ & $1.7686 \mathrm{E}-014$ & 3.6818 \\
\hline Residual & 9 & $4.3234 \mathrm{E}-014$ & $4.8038 \mathrm{E}-015$ & $\times$ \\
\hline Total & 11 & $7.8608 \mathrm{E}-014$ & $\times$ & $\times$ \\
\hline
\end{tabular}

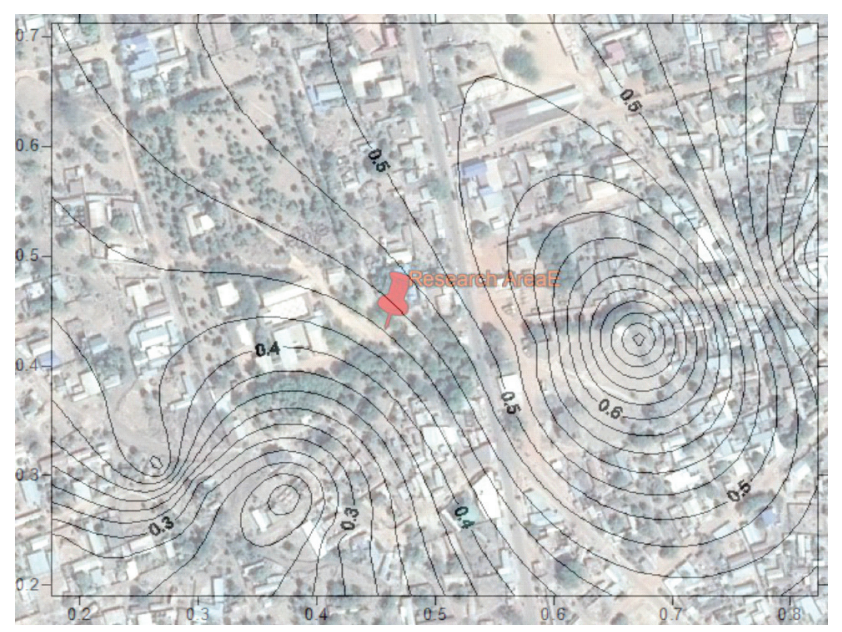

FIGURE 8. Spatial distribution of aerosol optical depth. Map scale $1: 200000$

osol loading and aerosol radius. The aerosol optical depth distribution reveals that the main pollution source in Dapaong is the agrarian area (Fig. 8). The Angstrom exponent over Dapaong is shown in Ta- bles 3, 4 and 5. The statistical analysis of the AOD dataset obtained from MISR is shown in Tables 6, 7 and 8. This statistical values (i.e. number of values, number of missing values, minimum, maximum, 




FIGURE 9. Spatial distribution of aerosol loading depth. Map scale $1: 200000$

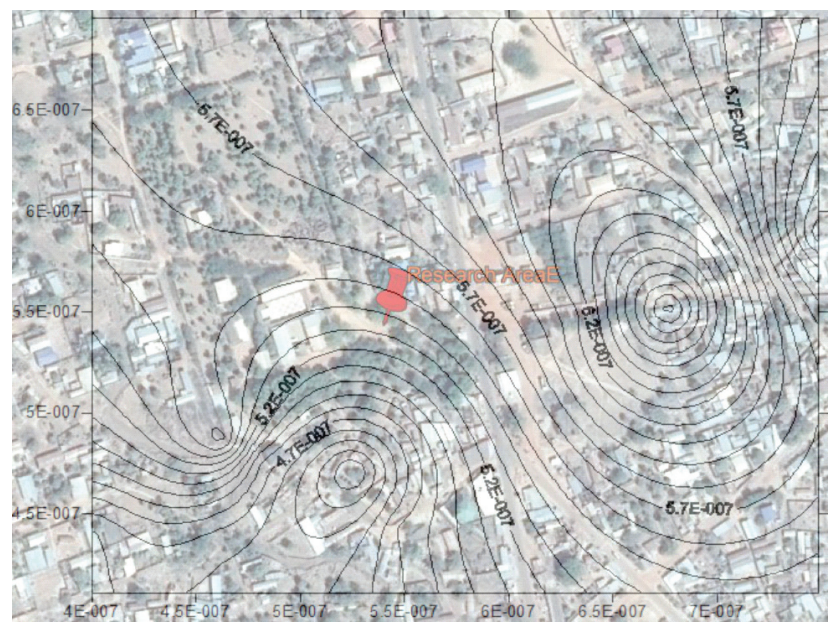

FIGURE 10. Spatial distribution of aerosol radius [m]. Map scale 1:200 000

mean, first quartile, third quartile, standard error, $95 \%$ confidence interval, $99 \%$ confidence interval, variance, average deviation, standard deviation, coefficient of variation, skew, kurtosis, Kolmogorov-Smirnov, critical K-S stat for $0.1,0.05$ and 0.01 ) give insight on the reliability of remote sensing techniques in aiding the present research. The average and standard deviation are considerable low and consistent. The standard error show that the dataset is very reliable in taking a confident conclusion. Due to forces of wind and advection, the aerosol loading shifts in the opposite direction (Emetere, 2016) where there is human settlement (north-east of Fig. 9). Like the AOD, the spatial distribution of the aerosols radius is in tandem to the pollution sources (Fig. 10). Hence, it is confirmed from 
TABLE 3. Angstrom exponent over Dapaong

\begin{tabular}{|l|c|c|c|c|c|}
\hline Month & 2000 & 2001 & 2002 & 2003 & 2004 \\
\hline Jan & \#NUM! & 0.10295458 & 0.0537552 & 0.1037909 & 0.18348319 \\
\hline Feb & \#NUM! & 0.03082767 & 0.11117707 & 0.17259845 & 0.044895 \\
\hline March & 0.062905356 & 0.13578512 & 0.04915511 & 0.09518643 & -0.0441758 \\
\hline April & 0.085117425 & 0.13747367 & 0.09883803 & 0.09702604 & 0.06002723 \\
\hline May & 0.048508737 & 0.10197187 & 0.1113902 & 0.17617092 & 0.15649097 \\
\hline June & 0.213179371 & 0.23361711 & 0.20545815 & 0.26703718 & 0.17449373 \\
\hline July & \#NUM! & 0.27492959 & 0.22985306 & 0.21257187 & \#NUM! \\
\hline Aug & 0.139180439 & 0.22717073 & 0.19159169 & 0.2930082 & \#NUM! \\
\hline Sep & 0.208383438 & 0.18688297 & 0.1270717 & 0.37418459 & 0.09204126 \\
\hline Oct & 0.192123638 & 0.19535342 & 0.19053313 & 0.17900636 & 0.25689057 \\
\hline Nov & 0.154938755 & 0.20051232 & 0.25443595 & 0.20131028 & 0.1249663 \\
\hline Dec & 0.250534672 & 0.26219338 & 0.20823588 & 0.22388052 & 0.15928059 \\
\hline
\end{tabular}

TABLE 4. Angstrom exponent over Dapaong

\begin{tabular}{|l|c|c|c|c|c|}
\hline Month & 2005 & 2006 & 2007 & 2008 & 2009 \\
\hline Jan & 0.10937691 & 0.14914834 & 0.11549531 & 0.23166688 & 0.12786851 \\
\hline Feb & 0.09446611 & 0.09663697 & 0.15606612 & 0.08376828 & 0.11714552 \\
\hline March & 0.0679297 & 0.05165763 & 0.01285179 & 0.11557741 & 0.02891637 \\
\hline April & 0.0757786 & 0.02276802 & 0.04246188 & 0.07355902 & 0.13541232 \\
\hline May & 0.16094911 & 0.16674224 & \#NUM! & 0.11516732 & 0.16146043 \\
\hline June & \#NUM! & 0.11369973 & 0.17835377 & 0.17165926 & 0.2804187 \\
\hline July & \#NUM! & \#NUM! & \#NUM! & 0.18688297 & 0.13690882 \\
\hline Aug & \#NUM! & \#NUM! & 0.16979743 & \#NUM! & \#NUM! \\
\hline Sep & 0.19159169 & \#NUM! & \#NUM! & 0.17568991 & 0.28466421 \\
\hline Oct & 0.26449149 & 0.25234331 & 0.23985626 & 0.27049642 & 0.18636832 \\
\hline Nov & 0.20858039 & 0.1873993 & 0.14161417 & 0.15229301 & 0.16109503 \\
\hline Dec & 0.22339283 & 0.16014893 & 0.14013666 & 0.15820183 & 0.25682373 \\
\hline
\end{tabular}

the above (Tables 1-4 and Figs. 4-10) that the main source of pollution over Dapaong is from anthropogenic source (June to December) and Sahara dust (January to May).

The last section focus on how this atmospheric aerosol affects human population in Dapaong. The deposition efficiency was estimated using Equation (4). The $D_{p}$ was substitute with the aerosol radius that was calculated in Figure 6. It is observed in Figure 11 that the highest deposition efficiency into human lungs occurred in 2000 and 2001. However, it has been very consistent in eleven years. The consistent value of the deposition efficiency is 0.955 . If an assumption is made that the deposition efficiency over Dapaong between 
TABLE 5. Angstrom exponent over Dapaong

\begin{tabular}{|l|c|c|c|c|}
\hline Month & 2010 & 2011 & 2012 & 2013 \\
\hline Jan & 0.22065731 & 0.12671885 & 0.16738655 & 0.23292604 \\
\hline Feb & 0.16168008 & 0.15564242 & 0.03057149 & 0.16109503 \\
\hline March & 0.0553936 & 0.0893744 & 0.05524395 & 0.11213845 \\
\hline April & 0.03044356 & 0.12980336 & 0.06599681 & 0.09846906 \\
\hline May & 0.07727581 & 0.09780706 & 0.15312374 & 0.0711219 \\
\hline June & 0.13766241 & 0.15663283 & 0.23818413 & 0.07744783 \\
\hline July & \#NUM! & 0.19053313 & 0.12974347 & \#NUM! \\
\hline Aug & \#NUM! & \#NUM! & \#NUM! & \#NUM! \\
\hline Sep & \#NUM! & 0.21875444 & \#NUM! & 0.19892837 \\
\hline Oct & 0.204591 & 0.10287877 & 0.31114461 & 0.18791731 \\
\hline Nov & 0.21729009 & 0.24547821 & 0.20060599 & 0.26639691 \\
\hline Dec & 0.17884296 & 0.14629745 & 0.1776228 & \#NUM! \\
\hline
\end{tabular}

TABLE 6. AOD statistics over Dapaong

\begin{tabular}{|l|c|c|c|c|c|}
\hline Statistics & 2000 & 2001 & 2002 & 2003 & 2004 \\
\hline Number of values & 9.0000 & 12.0000 & 12.0000 & 12.0000 & 10.0000 \\
\hline $\begin{array}{l}\text { Number of } \\
\text { missing values }\end{array}$ & 3.0000 & 0 & 0 & 0 & 2 \\
\hline Minimum & 0.2053 & 0.176 & 0.200333333 & 0.094 & 0.19725 \\
\hline Maximum & 0.736 & 0.823 & 0.733 & 0.548 & 1.322 \\
\hline Mean & 0.42366666 & 0.368847222 & 0.416006944 & 0.318006944 & 0.535275 \\
\hline First quartile & 0.266 & 0.23325 & 0.270625 & 0.214 & 0.332 \\
\hline Third quartile & 0.606 & 0.472875 & 0.515416667 & 0.4275 & 0.684333333 \\
\hline Standard error & 0.06476884 & 0.053854318 & 0.052598151 & 0.043333526 & 0.103058853 \\
\hline $\begin{array}{l}95 \% \text { confidence } \\
\text { interval }\end{array}$ & 0.1493569 & 0.118533353 & 0.11576853 & 0.09537709 & 0.233119125 \\
\hline $\begin{array}{l}\text { 99\% confidence } \\
\text { interval }\end{array}$ & 0.2172994 & 0.167271511 & 0.163369857 & 0.134593931 & 0.334941272 \\
\hline Variance & 0.0377550 & 0.034803451 & 0.033198786 & 0.022533533 & 0.106211272 \\
\hline Average deviation & 0.1602222 & 0.144835648 & 0.153743056 & 0.114631944 & 0.235446667 \\
\hline Standard deviation & 0.1943065 & 0.186556829 & 0.18220534 & 0.150111736 & 0.325900708 \\
\hline $\begin{array}{l}\text { Coefficient } \\
\text { of variation }\end{array}$ & 0.45863 & 0.50578 & 0.43799 & 0.47204 & 0.60885 \\
\hline Skew & 0.64 & 1.38 & 0.633 & 0.421 & 1.737 \\
\hline Kurtosis & -1.223 & 2.065 & -0.804 & -0.781 & 3.488 \\
\hline $\begin{array}{l}\text { Kolmogorov- } \\
\text { Smirnov stat }\end{array}$ & 0.187 & 0.213 & 0.238 & 0.203 & 0.198 \\
\hline
\end{tabular}


TABLE 6, cont.

\begin{tabular}{|l|c|c|c|c|c|}
\hline Statistics & 2000 & 2001 & 2002 & 2003 & 2004 \\
\hline $\begin{array}{l}\text { Critical K-S stat, } \\
\alpha=0.10\end{array}$ & 0.387 & 0.338 & 0.338 & 0.338 & 0.369 \\
\hline $\begin{array}{l}\text { Critical K-S stat, } \\
\alpha=0.05\end{array}$ & 0.43 & 0.375 & 0.375 & 0.375 & 0.409 \\
\hline $\begin{array}{l}\text { Critical K-S stat, } \\
\alpha=0.01\end{array}$ & 0.513 & 0.449 & 0.449 & 0.449 & 0.489 \\
\hline
\end{tabular}

TABLE 7. AOD statistics over Dapaong

\begin{tabular}{|c|c|c|c|c|c|}
\hline Statistics & 2005 & 2006 & 2007 & 2008 & 2009 \\
\hline Number of values & 9.0000 & 9.0000 & 9.0000 & 11.0000 & 11.0000 \\
\hline $\begin{array}{l}\text { Number of missing } \\
\text { values }\end{array}$ & 3.0000 & 3.0000 & 3.0000 & 1.0000 & 1.0000 \\
\hline Minimum & 0.1880 & 0.2030 & 0.2197 & 0.1810 & 0.1655 \\
\hline Maximum & 0.6510 & 0.8660 & 0.9220 & 0.6283 & 0.8330 \\
\hline Mean & 0.4090 & 0.4699 & 0.4721 & 0.3926 & 0.3786 \\
\hline First quartile & 0.2617 & 0.3380 & 0.3375 & 0.3126 & 0.2250 \\
\hline Third quartile & 0.5678 & 0.5876 & 0.5527 & 0.4827 & 0.4406 \\
\hline Standard error & 0.0579 & 0.0703 & 0.0752 & 0.0422 & 0.0566 \\
\hline $\begin{array}{l}95 \% \text { confidence } \\
\text { interval }\end{array}$ & 0.1337 & 0.1622 & 0.1736 & 0.0941 & 0.1260 \\
\hline $\begin{array}{l}99 \% \text { confidence } \\
\text { interval }\end{array}$ & 0.1945 & 0.2361 & 0.2526 & 0.13378 & 0.1793 \\
\hline Variance & 0.0303 & 0.04456 & 0.0510 & 0.0196 & 0.0352 \\
\hline Average deviation & 0.1524 & 0.1641 & 0.1672 & 0.1112 & 0.1289 \\
\hline Standard deviation & 0.1739 & 0.2111 & 0.2259 & 0.1400 & 0.1876 \\
\hline $\begin{array}{l}\text { Coefficient } \\
\text { of variation }\end{array}$ & 0.4253 & 0.4492 & 0.4785 & 0.3566 & 0.4956 \\
\hline Skew & 0.2290 & 0.8820 & 1.3000 & 0.3280 & 1.2990 \\
\hline Kurtosis & -1.7760 & 0.1300 & 0.9120 & -0.6070 & 2.9080 \\
\hline $\begin{array}{l}\text { Kolmogorov- } \\
\text {-Smirnov stat }\end{array}$ & 0.1830 & 0.2040 & 0.2710 & 0.1660 & 0.2090 \\
\hline $\begin{array}{l}\text { Critical K-S stat, } \\
\alpha=0.10\end{array}$ & 0.3870 & 0.3870 & 0.3870 & 0.3520 & 0.3520 \\
\hline $\begin{array}{l}\text { Critical K-S stat, } \\
\alpha=0.05\end{array}$ & 0.4300 & 0.4300 & 0.4300 & 0.3910 & 0.3910 \\
\hline $\begin{array}{l}\text { Critical K-S stat, } \\
\alpha=0.01\end{array}$ & 0.5130 & 0.5130 & 0.5130 & 0.4680 & 0.4680 \\
\hline
\end{tabular}


TABLE 8. AOD statistics over Dapaong

\begin{tabular}{|c|c|c|c|c|}
\hline Statistics & 2010 & 2011 & 2012 & 2013 \\
\hline Number of values & 9 & 11 & 10 & 9 \\
\hline $\begin{array}{l}\text { Number of missing } \\
\text { values }\end{array}$ & 3 & 1 & 2 & 3 \\
\hline Minimum & 0.248 & 0.212 & 0.14 & 0.18575 \\
\hline Maximum & 0.825 & 0.5685 & 0.824333333 & 0.638 \\
\hline Mean & 0.446796296 & 0.402204545 & 0.432541667 & 0.40512963 \\
\hline First quartile & 0.269208333 & 0.317916667 & 0.2815 & 0.27075 \\
\hline Third quartile & 0.636416667 & 0.50375 & 0.659 & 0.5558125 \\
\hline Standard error & 0.071457694 & 0.035110981 & 0.070983404 & 0.056252884 \\
\hline $\begin{array}{l}95 \% \text { confidence } \\
\text { interval }\end{array}$ & 0.164781442 & 0.078227265 & 0.160564461 & 0.129719151 \\
\hline $\begin{array}{l}99 \% \text { confidence } \\
\text { interval }\end{array}$ & 0.239740562 & 0.111266698 & 0.230696065 & 0.188728427 \\
\hline Variance & 0.045955818 & 0.013560591 & 0.050386437 & 0.028479483 \\
\hline Average deviation & 0.178432099 & 0.092329201 & 0.1798 & 0.146569959 \\
\hline Standard deviation & 0.214373081 & 0.11644995 & 0.224469234 & 0.168758653 \\
\hline $\begin{array}{l}\text { Coefficient } \\
\text { of variation }\end{array}$ & 0.4798 & 0.28953 & 0.51895 & 0.41655 \\
\hline Skew & 0.866 & -0.187 & 0.642 & 0.192 \\
\hline Kurtosis & -0.793 & -0.907 & -0.752 & -1.682 \\
\hline $\begin{array}{l}\text { Kolmogorov- } \\
\text {-Smirnov stat }\end{array}$ & 0.218 & 0.124 & 0.192 & 0.168 \\
\hline $\begin{array}{l}\text { Critical K-S stat, } \\
\alpha=0.10\end{array}$ & 0.387 & 0.352 & 0.369 & 0.387 \\
\hline $\begin{array}{l}\text { Critical K-S stat, } \\
\alpha=0.05\end{array}$ & 0.43 & 0.391 & 0.409 & 0.43 \\
\hline $\begin{array}{l}\text { Critical K-S stat, } \\
\alpha=0.01\end{array}$ & 0.513 & 0.468 & 0.489 & 0.513 \\
\hline
\end{tabular}

2002-2018 is true, then the report given by Borgen project (Borgen, 2018) that $20 \%$ of deaths in Togo is caused by respiratory diseases can be adjudged as very true.

\section{Conclusions}

Through a systematic investigation, it was affirmed that the main source of pollution over Dapaong is bush and do- mestic fuel burning (June to December) and Sahara dust (January to May). It was observed that the sources of pollution have been very consistent over two decades. The largest aerosol radius was found when the aerosol loading is presumably low. Hence, at high aerosol loading, the aerosol radius is very small to penetrate the nostrils into the lungs. The depositional efficiency of aerosols 


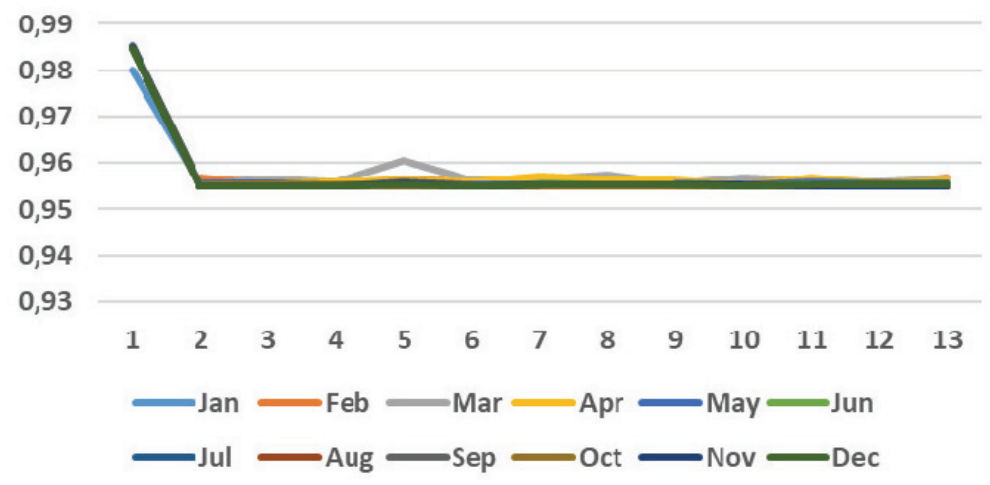

FIGURE 11. Deposition efficiency in human lungs versus year

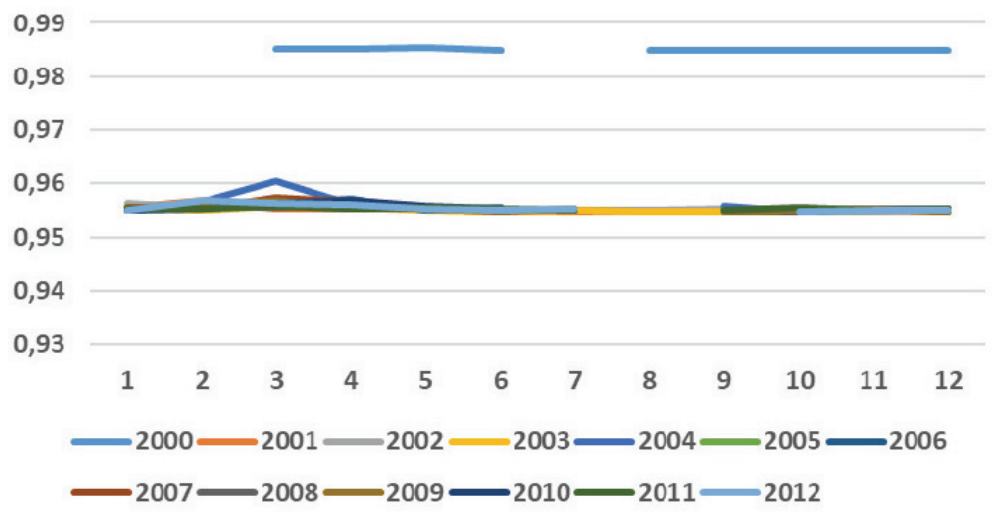

FIGURE 12. Deposition efficiency in human lungs versus month of year (2000-2013)

was estimated as 0.955 . If an assumption is made that the deposition efficiency over Dapaong between 2002-2018 is true, then the report given by Borgen project (that $20 \%$ of deaths in Togo is caused by respiratory diseases) may be adjudged as very true.

\section{Acknowledgements}

The authors appreciate Covenant University for partial sponsorship. The authors acknowledge NASA for primary dataset. The authors declare that there is no conflict of interest for this research. M.E. Emetere enjoys partial sponsorship as a Senior Research Associate at University of Johannesburg.

\section{References}

Bequemin, M.H., Yu, C.P., Roy, M. \& Bouchikhi, A. (1990). Total deposition of inhaled particles related to age: comparison with age dependent model calculations. Third International Workshop on Respiratory Tract Dosimetry, 1-3 July, Albuquerque, New Mexico.

Borgen (2018). Common diseases in Togo. Retrieved from: https://borgenproject.org/com- 
mon-diseases-in-togo/ (accessed: 30.07. 2018).

Ching, J. \& Kajino, M. (2018). Aerosol mixing state matters for particles deposition in human respiratory system. Scientific Reports, 8, 8864 .

Edwards, D.A. (1995). The macrotransport of aerosol particles in the lung: Aerosol deposition phenomena. Journal of Aerosol Science, 26(2), 293-317.

Emetere, M.E. (2016a). Numerical modelling of west africa regional scale aerosol dispersion. (a doctoral thesis). Ota: Covenant University.

Emetere, M.E. (2016b). Generation Of Atmospheric Constants Over Some Locations In West Africa: A Theoretical Aid for Measuring Instruments Design. International Journal of Engineering Research in Africa, 27, 119-146.

Emetere, M.E. (2016c). Statistical Examination of the Aerosols Loading Over Mubi-Nigeria: The Satellite Observation Analysis. Geographica Panonica, 20(1), 42-50.

Emetere, M.E., Akinyemi, M.L., \& Akinojo O. (2015) Parametric retrieval model for estimating aerosol size distribution via the AERONET, LAGOS station. Environmental Pollution, 207(C), 381-390.

Darquenne, C. \& Kin Prisk G. (2004). Aerosol Deposition in the Human Respiratory Tract Breathing Air and 80:20 Heliox. Journal of Aerosol Medicine, 17(3), 278-285.

Goikoetxea, E., Murgia, X., Serna-Grande, P., Valls-i-Soler, A., Rey-Santano, C., Rivas, A., ... \& Lopez-Arraiza, A. (2014). In vitro surfactant and perfluorocarbon aerosol deposition in a neonatal physical model of the upper conducting airways. PLOS ONE, 9(9), e106835.

Hofmann, W. \& Koblinger, L. (1992). Monte Carlo modeling of aerosol deposition in human lungs. Part III: Comparison with experimental data. Journal of Aerosol Science, 23(1), 51-63.

Jakobsson, J.K., Hedlund, J., Kumlin, J., Wollmer, P. \& Löndahl, J. (2016). A new method for measuring lung deposition efficiency of airborne nanoparticles in a single breath. Scientific Reports, 6, 36147.

Kokhanovsky, A.A., von Hoyningen-Huene, W. \& Burrows, J.P. (2006). Atmospheric aerosol load as derived from space. Atmospheric Research, 81, 176-185.

Martonen, T.B. \& Zhang. (1992). Comments on recent Data for Particle Deposition in $\mathrm{Hu}-$ man Nasal Passages. Journal of Aerosol Science, 23, 667-674.

Newman, S.P., Clark, A.R., Talaee, N. \& Clarke, S.W. (1989). Pressurised aerosol deposition in the human lung with and without an "open" spacer device. Thorax, 44, 706-710.

Schiller-Scotland, Ch.F., Hlawa, R., Gebhardt, J., Wönne, R. \& Heyder, J. (1992). Total deposition of aerosol particles in the respiratory tracts of children during spontaneous and controlled mouth breathing. Journal of Aerosol Science, 23, S457-S460.

Varghese Suresh, K. \& Gangamma, S. (2006). Particle Deposition in Human Respiratory Tract: Effect of Water-Soluble Fraction. Aerosol and Air Quality Research, 6(4), 360-379.

Yu, C.P. \& Xu, G.B., (1987). Predicted deposition of diesel particles in young humans. Journal of Aerosol Science, 18, 419-430.

\section{Summary}

Aerosol loading and its effect on respiratory dysfunction disorder over Dapaong-Togo. It has been reported that respiratory dysfunction is responsible for $20 \%$ of deaths in Togo. There is need to know (in numerical value) the current state and future prediction of aerosol loading over the research site. The research is based on remote sensing techniques and proven mathematical models. Fifteen years primary (aerosol optical depth) dataset was obtained from the Multi-angle Imaging Spectro-Radiometer (MISR). The secondary datasets (aerosol loading, particles sizes, Angstrom exponent and the statistics of the primary dataset) was generated from the primary data. The average deposition efficiency of aerosols (into the human lungs) in the region is about 0.955. This research provides vital data for health referencing and on-ground investigation over Dapaong-Togo. 
Authors' address:

Moses Emetere

Covenant University

Department of Physics

Canaan land, P.M.B 1023, Ota

Nigeria

e-mail: moses.emetere@covenantuniversity.edu.ng 